\title{
The Heritage of Banjar Kingdom from the Perspective of Social Inclusion and Entrepreneurship Education
}

\author{
Taufik Arbain \\ Faculty of Social and Political Sciences \\ Lambung Mangkurat University \\ opinibanua@gmail.com
}

\begin{abstract}
The Banjar Sultanate's policy in the past could answer all the problems of its time even reaching its golden age. Sultan Suriansyah is a figure who upholds equality of rights, justice, and protection. It shows pluralism that respects the attitude of social inclusion in the human context and the entities of a dignified nation. The Kingdom built this construction on the ideology of the empire rested on the values of Islam. The kingdom gives privileges by making open policies in a trade so we know it as a merchant state today. Banjarese entrepreneurial skills are bound by religious values as a form of the entity Baiman Bauntung Batuah.
\end{abstract}

Keywords: inclusion-exclusion social, heritage Banjar kingdom

\section{INTRODUCTION}

Issues related to social inclusion are now interesting themes that are discussed in various perspectives. Both the sociological perspective, anthropological, public policy education to economic development and regional development. Social inclusion as early presented to debate the existence of social exclusion behavior counters to the respect of others. For social inclusion by experts defined as efforts to put the dignity and autonomy of the individual as the primary capital to achieve ideal quality of life.

In this context, all elements of society are treated equally and have equal opportunities as citizens, regardless of any differences. Inclusive is a social movement to embrace citizens who experience stigma and marginalization to invite the public to act inclusively in everyday life.

The study of social inclusion this century is dominated in education in the view of humans which has special limitations, especially related to the possibility of its application in educational practices in schools. The study of development perspectives, for example, is interesting to observe. Wirth saw the aspect of inclusion of social in the development of urban areas in Indonesia as a result of economic growth lead is not followed by proper management and lack of infrastructure (urban sprawl) that have implications on poverty, conflict, and violence leads to behaviors of exclusion social [1]. Research that examines the New Order era was explained, that the vision and mission, as well as policy options, are only oriented economic development model minded would produce social exclusion in the form of poverty, inequality, and control of assets by a handful of people. Especially in the era of decentralization in Indonesia since the 2000 s led to the acceleration behavior cons of inclusion at the level of citizens and regional entities and leaving what we call social deprivation. The experts finally provide advice and recommendations that support development policies and social aspects [2].

Studies and discussions of social inclusion in a sociocultural perspective are very rare, especially exploring the similarities in social inclusion behavior in the last few centuries during the kings/imperial era. Because social inclusion term itself has a place in the social theories of the 20th century to see the reality of development that is oriented on economic growth, teaching and education are still discriminatory and lack cohesion and social solidarity. Notes on the similarity of behavior of social inclusion as cultural heritage can be seen from social institutions and social systems, including amendments by the passage of time and the process of assimilation, acculturation able to explain the ebb and flow dynamics of social inclusion and social exclusion happens.

In Banjarese, important events that put resemblance to the behavior of the inclusion or exclusion of social can be resting on the dynamics of the society in the past, although references describe past events (historically) events of the arrival of Islam as royal religion, trade and networks, Banjar Diaspora and war. However, no link between the behavior-driven social inclusion of customary and religious mandate (Islam), but on the other hand the entrepreneurial spirit of the process patterns (entrepreneurship) in the community because of the strengthening of trade in the past that has been implicated in social exclusion.

The above discourse will put and explain the position of social inclusion and exclusion in Banjar society. Is building social inclusion and social exclusion in society are part of the social capital that exists as a local ingenious and cultural heritage past, particularly in the Sultanate of Banjar? Or that there are factors that give birth determinant of social inclusion and social exclusion in a society Banjar royal fruit of political systems and trade dynamics of the past century? This paper attempts to map the existence of social inclusion and social exclusion and entrepreneurship from the perspective of the cultural heritage of the Sultanate of Banjar.

\section{SOCIAL INCLUSION IN HISTORICAL RECORDS}

Banjar nation for the majority ethnic community in Borneo is known as a trader. Geographical location close to the beach and the area has many rivers, affect the choice of occupation, characteristics and socio-cultural system. Settling as a trading nation, enduring, contemporaneous with the hybrids of the 
Banjar people from various mixed identities into the Banjar. This hybridization gave birth to new civilizations for the new entity in identifying as a new nation, the Sultanate of Banjar.

Fong [3] spread his views in the Trade and Politics in Banjarmasin from 1700 to 1747 , that nation is mixing Malay Banjar, foreigners and Java. A different note with Idwar Saleh asserted mixing Malay Ngaju, Maanyan, Bukit merging to undergo confirmation as the nation Banjar after their royal authority.

The words of Sultan Suriansyah as the first king who was considered sacred, "O my people, who are biaju, dusun, bukit, balandean, Javanese who live in the mountains and the beach are my people, then you live peacefully under my protection", is a response to political events that are very tense for the kingdom.

In this context, there are two important notes, the presence of the royal edict against the prevailing political dynamic economy it is especially in the 1500s in support of the behavioral study of their social inclusion. First, the multiethnic, multicultural reality of the new nation must be affirmed in the emperor's edict to build solidarity and social relations and equality (except strata based on position in the kingdom and royal family/nobility). A side from being a political kingdom in accommodating the interests to build a new country that could potentially be the great empire that was in the river mouth as the kingdom's economic potential. Mixing mating is a necessity that must be faced by the nation when it was formed from the strong flow of migration to the region in southeast Kalimantan whether caused motif warfare, runaway and trading patterns [4]. The multi-ethnic population inhabits the new Kingdom has built social inter-ethnic relations in spite of habitation space to form groups. Their ethnics distribution of power to all affirmed the implementation of the Sultan's edict which the next sultan had to pass.

At the beginning of the kingdom, for example, the wife of Sultan Suriansyah of Kapuas Biajo, the second king of Panembahan Maruhum, during childbirth which involved many uncles and mother's cousins in the palace to do royal duties. Acceleration increasing the inter-ethnic mixing of reality in a matter related to the royal family other than the expansion of power. Then in the early 1700s, Liam Kim $\mathrm{Ke}$, a Chinese lieutenant got the knighthood of Kyai Roxa, and a Gujarati got the title of Prince of Marta in terms of trade between foreign merchants and perform the duties of port or syahbandar [3]. For the kingdom where two strangers are important, because the kingdom must be allowed to reach the kingdom for international business relations, especially the pepper trade, the gold-diamond and forest products such as resins and agarwood (see subchapter Pasar Lada dan Jiwa Entrepreneur Banjar).

Second, the political message that the kingdom of King protects from the threat of conflict, encourage the behavior to maintain peace and unity in the new state entity. At the time it was suspected that no one had firmly confirmed the Banjar entity because it was still in the process of smelting ethnic entity and established a new social system under the auspices of the kingdom (see the lawyer-Indonesian since 1945). Considering Islam as the legal system in the kingdom based on the result of a political contract with Demak, then this is the religious ideology referenced every rulings king, especially those who embraced Islam. The implication influence of the Mufti and Tuan Guru can reach the people to become the construction of social and cultural systems as well as rules of customary communities facilitated Banjar kingdom.

Nevertheless, the Sultanate had the responsibility and care for people of multi-ethnic groups in the early centuries of the Banjar Sultanate as a plurality space, although the kingdom retained the power of legitimating power to play hegemonic politics regarding the ideological state Rooted in Islam as a palace religion as a result of the agreement with the Kingdom of Demak is not surprising, as Fong noted [3]. Banjar as religious communities and the strength of royal rule which puts religion as a source of law. Banjar rarely makes political and economic decisions without first obtaining the advice of the Mufti of the Kingdom.

Expansion of this royal ideology continues to expand into inland areas and some small kingdom became vassal for the kingdom of Banjar, followed by melting a massive variety of entities into a social and political entity into the nation Banjar. Friction ripples cannot be denied, as is generally accepted, that the choice of trust causes the segregation and segregation of relations between spaces of residence that occur, and the process of transferring beliefs often occurs in groups. The existence of the term "masjid parpantangan" in Halat Banua Tapin district, Banua Lawas Kelua, as the record of is the implication of differences in beliefs by putting the commitment of brotherhood between the groups and Maanyan and declaring Ngaju to be The Banjar of Islam and remaining at the origin of the belie. However, the passage of time gave rise to the superior attitude of those who declare into Banjar against relatives still living in the interior and were still underdeveloped. Exclusivism attitude began to climb when justifying to anyone who behaves "malalain", stupid, dirty and less dressed as "Urang Bukit, Urang Dusun, countrified". Whereas designation Urang Bukit is a reference to the entity that inhabits the hills of Meratus before the 1980s declaring as Dayaks Meratus and designation Urang Dusun to Maanyan is indeed from the beginning [5].

These realities are monumental events of the past in looking at social relations related to social inclusion and social exclusion, the relationship between those who declared the Banjar and those who remained on the old entity (urang Maanyan and Bukit) until the 1980s, but since the beginning of the King first laid the foundation for pluralism and built social inclusion that respects and protects each other. As a result of events that can be said almost applies to many entities in the world became a separate note to "release" the designation of the entity under the name of the place/topography (spatial), except those who inhabit the Hulu Sungai still called by Urang Hulusungai or Urang Pahuluan, due to its connotation is different in social relations that occurred.

This means that when referring to the concepts and definitions, social inclusion or exclusion of social existence in society is not without cause. Some factors contribute to the magnitude of the determinant of the presence of social inclusion and social exclusion in society. Poverty, the construction of the social system of politics, the application of ideology, social strata, environmental differences, different entities, mindset and experiences of life are among the factors that determine how strong the inclusion of social and exclusion 
social in a society itself, as occurs in society Banjar since the Sultanate until now.

Furthermore, if there are any cultural heritage and the Sultanate of Banjar which has similar behavior against the order of social inclusion? Moving on from the record that the edict the Sultan as a form of social inclusion behavior embodiment followed by the traditional order and religion of Islam that serve as the Palace of encouraging social inclusion behavior. This can be traced to some of the following views: First, the social construction Baiman Bauntung Batuah is a philosophy of life for the Banjarese which is reflected in the idea and hope of the kingdom (the State), to be felt for all nations. Baiman Bauntung Batuah, not just in the hope of a personal nature, but in the group of entities up to the kingdom. This can be seen from the royal policy instruments that promote religious values of Islam either in the text of correspondence, the sharia laws of the kingdom, the royal seal, including policies of the royal order of life, customs and manners of art and cultures. This condition applies to the sultans followed, including the era of Sultan Adam who issued a legal product called Undang Undang Sultan Adam, leaning to Ahlusunnah Wal Jamaah and provide space and a stage in making the Banjar entity and kingdom become Baiman Bauntung Batuah. The reality of the kingdom that rests on the policy of the teachings of Islam, known as "adat bersyandi syarak, syarak bersyandikan Kitabullah", which confirms bound with Islamic teachings.

This social construction eventually became the characteristic of the Banjar people to be a nation that obeys ceremonial and religious values (Islam). Every nation is driven into a human Banjar faith, so that contents of the law firm told the sultan with the device presented in the form of build violate religious and mosques, as well as the Koran and the obligatory Friday prayers. The context of faith in all of this became a foundation of the behavior that leads to forms of social inclusion. Construction to Islamization finally the largest contributor to strengthening and weakening of social inclusion. And share a penchant pay zakat, penchant festivity events (baaruhan), putting attitude towards his brother lakum dinukum waliaddin other religions, like to assist schools and religious education institutions to create a Quranic generation,

However, social inclusion from social beings continues to move from religious values. There are more important attitudes that contribute and succeed in matters affirmed by religion with light interpretations that they understand. This argument is to give an example of their choice, which is better, encouraging the repair of public roads, repairing a collapsed bridge or encouraging the repair of a damaged mosque or just donating some funds. There is an assumption that charity in religious activities is far better than scholarships, school fees for the disabled. Without doubt, the implications of the religious domain give rise to "individual piety" derived from social forms of exclusive pilgrimage many times, umrah many times, except for large-scale banquets in the village as social inclusion, but sometimes carried out based on the pattern "prestige" and the fight for the title" Hajj "from "bauntungan", lifelong achievements.

the virtue of the outputs as mentioned before still uses ceremonies which are bound by "prestige/ riya" in the eyes of a layman. But also not a few behaviors that place the ceremony has been "paid off" by the form of social inclusion, philanthropy, great appreciation for the poor and orphans, social activities of non-religious communities, although based on limited surveys namely attitudes and behavior as well as respect for fellow human beings based on religious beliefs (Islam) in Banjar society. Because it becomes legitimacy for the Banjar community that the achievement of "Batuahan" for a lifetime, must be based on the behavior of all believers "Beimanan", and all of the Luck "Bauntungan". All life is often interpreted as luck on welfare.

\section{PEPPER, MARKet, AND THE ENTREPRENEUR SPIRIT OF THE BANJAR COMMUNITY}

Posts Korte entitled The Great Turning, seems appropriate in understanding the development options polarizing debate about social exclusion and social inclusion. Korten warned that the development is too oriented to growth and has resulted in social exclusion and the three major crises, namely violence, poverty, and environmental destruction. The third issue is very complex so that if a country wants to get out of this problem, the development should focus on the socio-cultural dimension in social development that is currently known by the development of inclusion.

Indonesia and some developing countries in the early 20th century the world experienced such a situation when it deals with the growth model of development as the right choice. Offer this growth model in the development of even more aggravating inequalities and poverty, especially developing countries lured with loans and borrowings that are encroaching upon the exploitation of natural resources and impact on the future of the environment. For example, see the debate between physical capital, human capital and natural capital in the context of improvement of people's life quality [6]. One side of the selection of natural capital that finance infrastructure, security, education financing to increase human resources in the selection maximizes the effect of dignified social inclusion.

Arguments facts noted above, at least it becomes easier to understand how the relevance of the heritage of the Sultanate of Banjar in the context of inclusion-exclusion social and mental entrepreneurs among the policy choices of the Sultanate in the struggle for the seizure of economic resources, competition and trade relationships between foreign nations, as well as the relationship between trade competition good folk living in the kingdom's economic center and hinterland. That at certain times the kingdom adopted a monopoly policy of trade in people to assert the position of the kingdom that interacted in large-scale trade with foreign merchants. This is, also, to assert control aspects and ranges of power to the region, the people trading activities, as well as income for the interests of the kingdom and the royal family. On the other hand, for the people of the kingdom's presence in trade intervention forms part of their protection, trade conflicts that occur between Banjar merchants and foreign traders were very competitive at that time. Fong wrote, in 1700-1747 frequent trade competition until the burning barn, burning the ship to a murder committed all parties in the Kingdom of Banjar trade deal [3].

Robust royal intervention in the interest of maintaining political and economic stability provides a great opportunity to the people of Banjar to conduct trade relations with farmers and planters in Hulu Sungai, including urang Dusun and urang Bukit in the hinterland. The kingdom took steps to enliven international port and business interactions, and the release of 
foreign monopoly businesses interacted through the interior. Such conditions, at least encourage Banjarmasin residents, inland Hulu Sungai and build rubber plantations on the Pelaihari, pepper on a large scale to create conditions of trade interactions from small, medium to large scale which is ruled by the kingdom.

It is assumed here that one of the early milestones of the acceleration of entrepreneurial spirit in the Banjar country, to be recognized by the Dayaks as trading people up to now, because initially the collection of forest products such as damar, aloes, and rattan, is also a space for Banjar people providing community needs inland to build markets throughout the interior. In this case, the Banjar people interact with the group Ngaju, Maanyan, and Bukit in the hinterland. Moreover, the economic sensitivity is not just to make Banjarese partially into the Pemaklaran (middlemen), but building new business areas in the rural areas into smaller markets from monthly to weekly.

Note Linbad describes Hulu Sungai, Pelaihari, Kapuas, Barito and its hinterland is a major field of trade for Banjar people who sailed down the rivers to the inland [7]. The Banjarese perform the procedures and mechanisms for interacting with the interior of this group. The Banjar people understand mute transactions with shy Dayaks. Something that can't be done by Chinese, Bugis, Javanese, and Europeans.

However, the living area Dayaks seldom visited by outsiders, it becomes a strategy for people to bring the traditional group of the Banjar people. The Banjar people actively enter their customary land. Customary territories, which are mostly inhabited by timid Dayaks, are an opportunity for Banjar people to make money, especially trading with barter. The large profits and were able to gather a wealth of trading process, terraced up to a multinational merchant collector reinforce Banjar people controlling the areas of their trade and the protection of the kingdom that no foreign party to interfere with the people's business district.

In this case, the entrepreneurial mental heritage of the Banjar people for the benefit of doing business is based on interventions that affirm the Kingdom as the State of Commerce, Malay Muslims who control the port, ports have been instrumental in playing the role of businesses that need to lift capable men from among Chinese and Gujarat. At 16th-century, Sultanate of Banjar in a variety of conflicts with Mataram and several other kingdoms beginning of the struggle for international business interests, even expansion of power into several kingdoms in Kalimantan across West to East in the interests of mastery of business and protection of the kingdoms declare become vassal of Banjar Kingdom.

The economic expansion that made the kingdom with power expansion is based on the aspect of external stimulus in the form of the global demand for spices, pepper, sandalwood, gold, rattan, and other natural products. While the internal stimulus is their favorable geographical location is in the mouth of the river and the sea close to the coast with a population that is relatively correlated with economic dynamics. This condition makes the port a central role. Saleh notes, streams and the harbor became the main factors supporting the rapid development of the Sultanate of Banjarmasin centered on the banks of Kuin and is geared towards two major rivers, namely Sungai Barito and Martapura River [8]. Mastery of the river and the area traversed encourage Banjar.

This condition is followed by the social demographics of Banjar people who already have skills in business so that waves of migration are formed in all directions to obtain a harmonious place and relationship in understanding the traditional mechanisms of their destination areas. Linbad cites Feulletau de Bruyn for example reporting waves of migration to the east by Banjar traders that occurred during the Banjar war crisis until Banjar traders mingled with other traders in Mahakam [7]. Moreover, Sultan Kutai's invitation to Banjar to become a fisherman and trader to help build Kutai and help business trade relations between Dayaks and Bugis always creates conflict.

In this case, Linbad, et al does not explain other aspects in the course of the migration of Banjar either because of economic incentives and motives of the defeat of the war that led them to survive [7]. Arbain noted that the circulation of Banjar people especially those who are good traders into many areas east and west of the island of Borneo, get the "special protection" and assured by fellow ethnic Banjar who is in overseas until age 21[9]. They are the dominant profession of these traders are the ethnic Banjar sub-Nagara, Alabio, Exodus, Barabai, and Amuntai. While sub-ethnic Banjar tends to protect on behalf of Banjar ethnic entity in the migration are those from sub-Kandangan, and overseas. This is a relationship of mutual benefit, in addition to factors royal intervention in the past.

The historical argument as presented previously by the author provides an analysis related to the entrepreneurial spirit of the heritage of the Banjar Sultanate: First, the kingdom's ability to play a multilevel political economy at Banjar people has prompted the opportunity for the people of Banjar to become beings of business, Kingdom divides the space capabilities to the people at a certain level according to the capacity and capability of interacting with foreign traders, and the capacity to interact with a traditional merchant up to the inland. Second, the kingdom at certain periods of expansion of political power to expand its influence and business interests, to control the economy and politics in addition to understanding the threats small kingdoms of attacks across the kingdom so do politics "protection" to the kingdom become a part of protection on behalf of vassal (federation). Third, the political effect of the expansion of the region with a mating approach, establishing a royal child region, protection of enemy attacks, seemed to make space and area for the people of Banjar towards other areas that become its vassal in the search for business opportunities and jobs in particular trade. Here, over time gave birth to the economic sensitivity of the soul entrepreneur for Banjar [9].

Then how is the mental effect for the Banjar entrepreneurs on social exclusion and social inclusion? The legitimacy of power to the control port confirms the non-continental approach (ocean/beach, river) and the port as an instrument of political and economic interest meeting (trade). Reality is finally formed national character response to globalization (of his time), in the form of trade interactions, interactions of education and cultural interaction. Nevertheless, the Sultanate has a responsibility and care for the multi-ethnic people in the early centuries of the Sultanate of Banjar, a plurality of space, even though the kingdom to maintain political power play 
rested every policy on the Islamic religious values in order of

hegemonic legitimacy of power over the state ideology "custom coded Personality,

As noted earlier, the economic sensitivity born of royal policy interventions has encouraged the spirit of the Banjar nation to be people who are always looking for opportunities and build businesses on the move. Militancy was born as a great opportunity and hope, Admittedly, this condition partly spawned social exclusion behavior that minimizes the inclusion of social behavior. Adapting the view of the experts strengthening the spirit of entrepreneurship lets forget the social ethics and tend to capitalism. That the contribution of capitalism is something that greatly influences the power of social inclusion in society. Fact 1 onwards industrial revolution offers capitalism seedlings grow entrepreneur souls. Capitalism is an ideology that rejects and contradicts the ideology of socialism, that socialism places the economy as a strategy for overcoming poverty and inequality which involves the main role of the State and society as unity. While capitalism places a minimalist and passive state, markets determine social activities.

Answering such challenges, the Kingdom confirms law "Custom coded Personality, Personality coded Book of Allah", thus encouraging the Mufti and master teachers to encourage the formation of man Banjar Baiman Bauntung Batuah. Shaykh Muhammad Al-Banjari Arsyad has laid the foundation of business ethics for Banjar people, which is a procedure for transactions "jualah-tukarlah" taken from the Koran and Hadith. The procedure for the presence of a business agreement is not without reason, but waves of groups of people to become entrepreneurs forced the Banjar kingdom to intervene through the palace clerics in the policies and rules of human relations. This reality, the entrepreneurial spirit of the Banjar people is not only the spirit in looking for opportunities to make but is based on religious values that encourage the maximization of social inclusion attitude.

\section{CONCLUSION}

Sultan Suriansyah becomes milestones and markers provide a dignified place to all entities' ethnicity, religion, and belief. An edict is a form of equality of rights and justice and human position, except for its taqwa. Kingdom importance the strengthening of relations between the power and reach of the kingdom and the people. A dignified relationship as an implementation of social inclusion, even though the dynamics are in the historical flux of inter-ethnic relations under royal control.

On the other hand, the kingdom had an interest in the trade and international relations in the framework of political and economic interests and political expansion of the area. Sultanate heritage in the form of political and economic intervention policy of the region, which is supported by the natural capital resources, the resource implications on entrepreneurship (entrepreneurship). Skill and tenacity overtime to justify the Banjar ethnic entity is known to have the ability to seize market spaces and business relationships with other parties who have their way according to their times. The foundation of the Kingdom's inheritance in the form of "privileges" for the Banjar entity and noble families encouraged social classes to bring up merchants and entrepreneurs in this century, compared to other entities for centuries. And the value of religion as an ideology of work, the spirit of intra-entrepreneurial struggle that allows trapped exclusively, can be bridged with the values of the kingdom (relics and policies) to maximize the attitudes and spirit of social inclusion.

\section{REFERENCES}

[1] P. Misselwitz, and T. Rienits, City of Collision: Jerusalem and the Principles of conflict urbanism. Basel: Birkhauser, 2006.

[2] W. Wasilah. "Pembangunan Inklusif Sebagai Upaya Mereduksi Ekslusi Sosial Perkotaan, Jurnal Masyarakat dan Budaya," Vol.17, No.2, 2015.

[3] G. Y. Fong, Trade and Politics in Banjarmasin 1700-1747. Surabaya: Lilin Persada, 2013.

[4] T. Arbain, Merawat Adat. Banjarmasin: Pustaka Banua, 2012.

[5] N. H. Radam, 2001. Religi Urang Bukit. Jakarta: Semesta

[6] T. Vinod, The Quality of Growth. Jakarta, Gramedia Pustaka Utama, 2001.

[7] J. T. Linbad, Antara Dayak dan Belanda: Sejarah ekonomi Kalimantan Timur dan Kalimantan Telatan 1880-1942. Jakarta. Lilin Persada Press, 2012.

[8] M. I. Saleh, Sedjarah Bandjarmasin. Bandung: KPPK Balai Pendidikan Guru, 1958.

[9] T. Arbain, Diaspora Banjar: Marwah Kesultanan, Kemelayuan dan Dampak Sosia budaya di Tanah Rantau, makalah seminar manuskrip Borneo, Brunei Darussalam, 2017. 